\title{
ФЕНОМЕН ЛЮБВИ: АНТИНОМИИ И ПАРАДОКСЫ
}

\author{
ИНЕССА MOРОЗОВА \\ Национальная академия наук Беларуси \\ Институт философии \\ Центр социально-философских и атропологических исследований \\ ул. Сурганова 1/2, 220072 Минск, Беларусь \\ e-mail: inesmorozova@bk.ru \\ ORCID: https://orcid.org/0000-0002-3566-331X \\ (получено 6.09.2018; принято 25.09. 2018)
}

\section{Abstract \\ Phenomenon of love: antinomy and paradoxes}

The article presents an analysis of the problem of love, its contradictions and paradoxes, as reflected in Russian literature of the second half of the 19th century. In particular, the works of K. N. Leontiev, F. M. Dostoyevsky and L.N. Tolstoy are considered in the context of the theoretical constructs of representatives of Russian and foreign idealistic philosophy, as well as individual writers of world fiction.

\section{Key words}

Love, passion, personality, conflict, estrangement, selfishness, morality, psychology.

\section{Резюме}

В статье представлен анализ проблемы любви, ее противоречий и парадоксов, отраженной в русской литературе второй половины 19 века. В частности, произведения К. Н. Леонтьева, Ф. М. Достоевского, Л. Н. Толстого рассматриваются в контексте теоретических построений представителей русской и зарубежной 
идеалистической философии, а также отдельных писателей мировой художественной литературы.

\section{Ключевые слова}

Любовь, страсть, личность, конфликт, отчужденность, эгоизм, нравственность, психологизм.

Эстетическое воплощение феномена любви в художественной литературе на протяжении ряда лет остается наиболее актуальной и востребованной темой литературоведческих исследований. Такой пристальный интерес обусловлен тем неоспоримым и весьма очевидным фактом постоянной притягательности, непроясненности и загадочности этого феномена, стремлением разгадать тайну любви и ее противоречий. «Любовь - настолько же вещь в себе, как и любой по-своему герметичный объект, требующий специального интеллектуального инструментария», причем такого инструментария, который будет отражать синтезированный подход в осмыслении данной проблемы, учитывая философский, психологический, социальный и иные аспекты, способствуя адекватному пониманию смысла любви в жизни человека. Удивительным остается то, что, несмотря на убежденность многих исследователей в отсутствии данности любви для большинства людей (любовь - редкое явление, дар и талант, которыми наделены немногие), это явление определяется высшей ценностью в системе нравственных координат и гармонизации бытия человека (Фромм, 2004, с. 23):

Есть только одна страсть, которая удовлетворяет потребность человека в его единстве с миром и в обретении при этом чувства целостности и индивидуальности, и это - любовь... Переживание любви кладет конец необходимости иллюзий. Здесь нет нужды лакировать образ другого человека или свой, так как реальность активного соучастия и любви позволяет мне выйти за пределы моего индивидуального существования.

Конечно, любовь окрыляет, она придает смелость и уверенность, снимает страхи, раскрепощает сознание, доходя до упоенности любовью. Человек живет ожиданием ее прихода, всегда такого неожиданного, волнительного, нарушающего привычный ход вещей, изменяющего траекторию индивидуального жизнеустроения. Не случайно героиня современной прозы, философски взирая на мир и человека в системе ценностей этого мира, осознавая противоречивые и сложные межличностные отношения двух противоположностей - мужчины и женщины, их неумолимое притяжение друг к другу, не исключающее, ко всему прочему, столь же частое отталкивание, определяет для себя общеизвестную констатацию, выкристаллизованную из наследия лучших умов научного знания:

Философия сущности женского и мужского начал - быть вместе. И, может, только благодаря этому можно выбраться из лабиринта бесцветности и монотонности жизни, и именно любовь избавит, спасет от сиротсва и бездомности сердце. И при этом сильная любовь чаще всего остается неразделенной и приводит к болезненному финалу. Но ни 
одна из них, по большому счету, не безнадежная, она всегда добро и счастье... (Шніп 2016, c. 36).

Но именно проблематичность построения идеальных (или приближенных к идеалу) межличностных отношений определяет драматизм и трагизм любви, заложенный в непреодолимой разделенности мужчины и женщины, невозможности абсолютного взаимного проникновения, поскольку составляя одно, любящие все равно остаются двумя разными существами. Более того, антиномичность любви часто обусловлена сложным взаимодействием нравственного и вненравственного уровней, усложняющим понимание самого феномена любви и специфики ее эстетической реализации в художественном творчестве, особенно представленных в отдельных прозаических произведениях Федора Михайловича Достоевского, Константина Николаевича Леонтьева и Льва Николаевича Толстого, рассмотреть которые следует более подробно. Необходимо отметить, что в творческом наследии представителей русского религиозно-философского ренессанса широко отражен факт осмысления сложной и противоречивой проблемы бытия человечества - проблемы эроса, любви. У известного русского теософа Петра Демьяновича Успенского есть замечательная мысль о том, что

(...) любовь - это глубоко мистический момент. Человек высокого развития должен очень много понимать через любовь. Ощущения любви должны давать ему новые и необыкновенные постижения. Любовь для него всегда будет чудом, в ней никогда для него не будет ничего простого. Он будет ощущать в любви тайну, и эта тайна будет для него главной, притягательной силой любви (Шестаков, 1991, с. 425).

Эти философские констатации очень точно характеризуют антропологию Федора Михайловича Достоевского, доминантой которой выступает, как известно, теза о тайне человека, уходящая в эстетическую реализацию тайны любви и ее противоречий. У Достоевского нет объяснения происходящему между мужчиной и женщиной, он осознанно моделирует именно таинственность, загадочность отношений двух в страсти, любви, как бы соприкасаясь с последующими сентенциями Петра Демьяновича Успенского о том, что «влияние женщины на душу мужчины и мужчины на душу женщины похоже на влияние природы на человека. Тут действует соприкосновение с той же самой тайной. Точно так же эта тайна влечет к себе и точно так же сильнее всего чувствуется в неизвестном, новом. Охватить ее или выразить в словах невозможно» (Шестаков, 1991, с. 230).

Такое понимание вопроса приводит Достоевского к акцентированию внимания на проблеме лица человека, аккумулирующего в себе и отражающего эту тайну. Николай Александрович Бердяев, представивший уникальные экзистенциальные постижения в области метафизики пола, эроса и любви, проницательно прозревает: «Любовь есть путь к раскрытию тайны лица, к восприятию лица в глубине его бытия. Любящий знает о лице любимого то, чего весь мир не знает, и любящий всегда более прав, чем весь мир» (Бердяев, 1994, с. 208). Так, одержимый страстью Рогожин, представитель дионисийной стихии у Достоевского, в сцене с горящими ста тысячами, брошенными Настасьей Филиппов- 
ной в камин, единственный из всех присутствующих при этом мужчин смотрит с восхищением на лицо любимой женщины, бесконечно гордясь ее поступком, этой русской широкостью, эффектно продемонстрированной героиней. Именно ему одному дано понять мотивацию и суть поступка Настасьи Филипповны, ему одному (одержимому страстью к женщине) дано прозреть тайну лица этой женщины, и именно в этом приоткрывается тайна и самого Рогожина. Мистицизм женского лица неразрывно связан у Достоевского с красотой, которая для писателя, как известно, также таинственна и непостижима, как человек, любовь, страсть. Она манит к себе, увлекает за собой, она притягательна и отталкивающа одновременно. Понимание Достоевским амбивалентности красоты нашло отражение в знаменитой тираде Дмитрия Карамазова:

Красота - это страшная и ужасная вещь! Страшная потому, что неопределимая, а определить нельзя, потому что Бог задал одни загадки. Тут берега сходятся, тут все противоречия вместе живут... Что уму представляется позором, то сердцу сплошь красотой... В Содоме-то она и сидит для огромного большинства людей... Ужасно то, что красота есть не только страшная, но и таинственная вещь. Тут дьявол с Богом борется, а поле битвы - сердца людей (Достоевский, 1976, с. 100).

Очень верно заметил Иннокентий Анненский о том, что Достоевский видел в красоте власть, но не столько пьянящую власть наслаждения, сколько «лирически приподнятую, раскаянно-усиленную исповедь греха» (Анненский, 1988, с. 535), реализуемую как в трагических образах женщин, так и мужчин. Красота мужского лица и притягательна, и таинственна, и порочна у Достоевского, недаром Ставрогин определен одним из самых загадочных образов мировой литературы, а Свидригайлов и по сей день воспринимаем односторонне и неадекватно.

Осознание Достоевским дуализма красоты позволяет расширить границы приемлемости прекрасного, красота для писателя обретает статус вненравственной принадлежности, она - внеморальна, неподсудна. Не случайно князь Мышкин в Идиоте произносит слова, на которые как-то мало обращают внимание: «Красоту трудно судить... красота - загадка». И речь в данном случае идет сугубо о внешней красоте женщины, мало согласуясь с осознанием духовного или нравственного в ней, вне границ религиозного мироощущения. Игнорирование христианских ценностей в этой ситуации вовсе не означает их полного отсутствия в эстетической системе Достоевского, это лишь свидетельствует о наличии этического (или внеэтического) эклектизма, проявленного как в личной жизненной судьбе писателя, так и трансформированного в его художественном мире. Эту эклектику трудно было принять и оценить как свершившийся факт религиозно настроенным философам и богословам, поэтому наблюдается столько смещений в плоскость одиозных тенденциознохристианских суждений в их исследованиях. Вложив в уста того же Мышкина знаменитую и заимствованную у Фридриха Шиллера мысль о спасительной силе красоты, Достоевский одновременно подводит читателя к пониманию необходимости спасения самой красоты, девальвированной, опошленной, о чем свидетельствует, например, тот факт, что инфернальная красота Настасьи Фи- 
липповны выставлена на торги, достаточно аморальные и циничные по сути своей. И нельзя согласиться в данном случае с мнением Василия Зеньковского, который в своей концептуальной работе Проблема красоты в миросозериании Достоевского говорит о неосознании Достоевским этого трагического факта (Зеньковский, 1991, с. 116).

Но Василий Зеньковский бесконечно прав в том, что «именно связь красоты с полом и создает ее загадку... Через пол душа все так же ищет красоты, как и вне его» (Зеньковский, 1991, с. 115). Представители русской религиозно-философской мысли неоднократно указывали на факт художественной реализации проблемы пола в романной прозе Федора Михайловича Достоевского, наиболее представленной в Идиоте, Бесах и Братьях Карамазовых. Николай Александрович Бердяев вообще считал вопрос о поле одним из центральных в жизни человека, имеющим всемирное значение:

С полом и любовью связана тайна разрыва в мире и тайна всякого соединения; с полом и любовью связана также тайна индивидуальности и бессмертия. Это мучительнейший вопрос для каждого существа, для всех людей он также безмерно важен, как и вопрос о поддержании жизни и смерти (Шестаков, 1991, с. 232).

И Достоевский утверждает трагическое состояние пола в человеке, его герои - мученики в половом отношении, не обретающие гармонии в онтологическом смысле, поскольку, как считает Николай Александрович Бердяев, «Достоевский недостаточно сознавал, что природа человека - андрогинна... И потому, быть может, так истерична женская природа у Достоевского, потому так надрывна, что она обречена на несоединенность с природой мужской» (Бердяев, 1994, c. 76).

Но эта трагическая несоединенность двух осуществляется и в иных сферах, как метафизических, так и онтологических, прекрасно осознаваемая Зигмундом Фрейдом, Эрихом Фроммом, Жан-Поль Сартром, Николаем Бердяевым, безапелляционно утверждавшем о духовном одиночестве человека: «...Мы всегда “одинокие” духовно, мы никогда не сливаемся с другими до полного, конечного единства души и тела, такое единство недостижимо в плоскости естественного бытия» (Шестаков, 1991, с. 327). Оно недостижимо еще и потому, что недосягаемым остается стремление в любви понять тайну человека:

Мы знаем себя, и все же, какие бы усилия мы ни делали, мы себя не знаем. Мы знаем своего ближнего и все же не знаем его... Чем глубже мы проникаем в суть собственного или чужого бытия, тем дальше отодвигается от нас цель познания (Фромм, 2004, с. 100).

Глубокое понимание Федором Михайловичем Достоевским метафизики трагической несоединенности усугубляет драматизм инфернальной стихии женщины, выражаясь в проявлении истерии, демонизма, стремлении властвовать над мужчинами и бесконечно мучить их. «Маленькое эмпирическое “я” стремится к самоутверждению в полном обладании... Эта жажда власти и господствования есть во всякой любви; без нее любить нельзя. Поэтому-то любовь и проявляется как борьба двух душ, борьба не на жизнь, а на смерть» (Борисов, Рогинский, 1990, с. 267). Демонические женщины Достоевского вы- 
зывали резкое эстетическое неприятие у Николая Михайловского, Николая Бердяева, а Сомерсет Моэм, проницательно выявляя садомазохистские наклонности в женской натуре, одновременно отказывался понимать такое состояние: «Стремясь властвовать и измываться над мужчинами, которых они любят, героини в то же время жаждут сами покориться им и терпеть от них муки. Нет, их не объяснишь» (Моэм, 1981, с. 273).

Парадоксальность эстетической ситуации заключается в том, что женщины Достоевского, наделенные притягательной красотой и таинственностью, влекущие к себе, вызывающие страстное чувство любви, обречены либо на конфликтное, дисгармоничное существование в мире, либо на отсутствие всяких жизненных перспектив. У Кэрола Льюиса есть потрясающая мысль о том, что «Бог и Его святые любят тех, кто не может вызвать любви» (Льюис, 1989, с. 118). Следовательно, те, кто эту любовь вызывают, по закону онтологической компенсации и принципам религиозной этики, обречены на мирозданную не-любовь, не-милость и трагическое существование в атмосфере вызванной к себе любви?! Не от осознания ли этой печальной мысли Фридрих Ницше говорил о том, что «страх и сострадание - вот те чувства, с которыми должен стоять мужчина перед женщиной, всегда одной ногой погруженной в трагедию, которая раздирает и в то же время восхищает» (Ницше, 1992, с. 149).

Федор Михайлович Достоевский преподнес такого мужчину, продемонстрировавшего страх и сострадание - князя Мышкина перед Настасьей Филипповной. Но князь Мышкин способен только на платоническую любовь, аскетико-христианскую; он девственен, потому как христоподобен, к тому же, инфернальной стихии Настасьи Филипповны нужна дионисийная стихия Рогожина, поскольку в Мышкине нет той агрессивности, того темного и мрачного, что оправдало бы Настасью Филипповну в проявлении своей демонической власти над ним, даже если это будет стоить ей жизни. В связи с этим, необходимо указать, что современные исследователи отмечают точи соприкосновения в эстетических системах Достоевского и Маркиза де Сада, в частности, в осмыслении онтологической проблемы зла и мрака в человеке, выявляя наличие морально-философских постижений Маркиза де Сада, апеллируя к его словам, сказанным задолго до Достоевского: «В человеке скрыто невероятно много грязного, темного, преступного. Человек способен на все. Обуздать его не могут ни штыки, ни тюремные решетки, ни осуждение близких» (Храмов, 1992, с. 3). Безусловно, такая констатация факта хаоса в человеке ярко представлена в творчестве писателя, и существование у такого человека в мире Федора Михайловича Достоевского является абсурдным, здесь прав Альбер Камю, утверждавший: «И никому, конечно, не удавалось придать абсурдному миру такой понятной и такой мучительной притягательности, как Достоевскому» (Камю, 1978, с. 253).

Вторжение же эроса в абсурдную стихию человека обостряет сферу чувственности до предела, толкая его на необъяснимые и трагические поступки. Но «эрос мстит жестоко за всякое малейшее принуждение... Эрос мирится только с одним принуждением и завоеванием: когда его принуждают к тому, чего он, в сущности, изначально и бессознательно желал» (Борисов, Рогинский, 
1990, с. 401). Такая ситуация эстетически обыгрывается Достоевским в романе Братья Карамазовы, где одержимый страстью к Грушеньке Дмитрий Карамазов постоянно живет на надрыве, на одном нерве, но терпит, как бы интуитивно прозревая, что Грушенька, бессознательно и осознанно одновременно, изначально была готова уступить одержимости Мити, и она дарует ему право на себя, поскольку он это право выстрадал, еще и потому, что

Влюбленный сознает... что, вопреки своей воле, он принадлежит тому, кого любит. И в этом нет никакого противоречия, ибо полное подчинение себя другому человеку происходит в таких глубинах личности, над которыми воля не властна. Он не жаждет подчиниться, а он подчиняется, не желая этого (Ортега-и-Гассет, 2003, с. 232-233).

Примечательно, что у Чарльза Диккенса в его неоконченном романе Тайна Эдвина Друда также представлена ситуация вторжения эроса в чувственную стихию человека, страстного любовного влечения, не оставляющего места жалости и снисхождению. Мистер Джаспер, учитель музыки, тайно и обреченно влюблен в свою ученицу, совсем еще юную девушку. Разница в возрасте, жизненном опыте и нравственных установках совершенно его не смущает, но свою тайну он может проявить только в скрытом стремлении подчинить волю и сознание девушки, увлекая ее в мир музыки:

(...) мистер Джаспер сидел за пианино и аккомпанировал Розовому Бутончику, а она пела...ггаза Джаспера не отрывались от ее губ, а руки словно держали на невидимой привязи ее голос...Пение продолжалось. Роза пела какую-то печальную песенку... А Джаспер по-прежнему неотступно следил за ее губами и по-прежнему время от времени задавал тон, словно тихо и властно шептал ей что-то на ухо - и голос певицы, чем дальше, тем чаще, стал вздрагивать, готовый сорваться (Диккенс, 1985, с. 54-55).

Изменившиеся жизненные обстоятельства подталкивают мистера Джаспера к более активным действиям, абсолютно не считаясь с чувствами и желаниями объекта своей одержимости. Парадоксальность и неоднозначность ситуации заключена в бестактном вторжении в личное пространство героини, желании прикоснуться к тайне ее личности, эгоистичном стремлении подчинить ее жизнь собственным прихотям, в посягновении на свободу ее действий и побуждений. «Есть один отчаянный способ познать тайну: он состоит в полной власти над другим человеком, власти, заставляющей его поступать, чувствовать и думать так, как мы хотим... Именно эта жажда проникнуть в тайну другого человека, а значит и в свою собственную тайну, в большой степени объясняет глубину и интенсивность жестокости и деструктивности» (Фромм, 2004, с. 101):

Роза... я любил тебя до безумия... днем, в часы моих скучных занятий, ночью, во время бессонницы, запертый, как в тюрьме, в постылой действительности, или блуждая среди райских и адских видений, в стране грез, куда я убегал, унося в объятиях твой образ, всегда, всегда, всегда я любил тебя до безумия!.. Вот мое зря потраченное прошлое и настоящее. Вот лютое одиночество моего сердца и моей души. Вот мой покой; вот мое отчаянье. Втопчи их в грязь; только возьми меня, даже если смертельно меня ненавидишь!. Если теперь ты отвергнешь меня - но этого не будет - ты от меня не избавишься. Я никому не позволю стать между нами. Я буду преследовать тебя до самой смерти (Диккенс, 1985, c. 179-181). 
Различные формы проявления индивидуальной деструктивности при эротической одержимости, отраженные в прозе Диккенса и Достоевского, как это ни странно, имеют одну общую особенность, связанную с парадоксальной природой любви, заключающей в себе непреодолимый конфликт, вечное противостояние свободы объекта любви и подчинении ее субъектом эгоистических притязаний, о чем неоднократно говорил Жан Поль Сартр, напоминая о том, что «кто хочет быть любимым, тот, напротив, не желает порабощения любимого существа. Его не манит перспектива стать объектом гнетущей механической страсти. Он не хочет обладать автоматом. Он хочет обладать свободой именно как свободой» (Гуревич, 1988, с. 21).

Трагическое осмысление любви, преобладающее в творческой системе Федора Михайловича Достоевского, тесно связано с проблемами морали. Лев Шестов как-то произнес парадоксальную, на первый взгляд, мысль о том, что «любовь всегда бестактна по сути своей», но в этом парадоксе заключен некий точный метафизический смысл, характеризующий проявления любви. Достоевский в своем творчестве моделирует преимущественно именно бестактность в любви, которая проявляется не только в мелочах, но и в стремлении подчинить себе любимого, ограничить его свободу, в чувстве собственности на него, в посягновении, в конце концов, на жизнь любимого человека, только в данном случае это уже не банальная бестактность, а преступление не только нравственного, но и религиозного, онтологического порядка. И Артур Шопенгауэр, и Зигмунд Фрейд указывали на ту необъяснимую драматическую ситуацию, когда любовь ослепляет настолько, что в этом любовном ослеплении человек способен совершить какое угодно преступление, абсолютно не раскаиваясь в нем. Художественный опыт Достоевского отражает эту трагическую ситуацию, подтверждая известное изречение Фридриха Ницше: «То, что делается из любви, всегда совершается по ту сторону добра и зла» (Ницше, 1992, с. 86).

Жизненный опыт Федора Михайловича Достоевского, его редкие и откровенные рассуждения о страсти, любви, зафиксированные в воспоминаниях Всеволода Сергеевича Соловьева, отражают всю ту же ницшеанскую констатацию «по ту сторону добра и зла»:

Нет, кто любит, тот не рассуждает, - знаете ли, как любят! (и голос его дрогнул, и он страстно зашептал): если вы любите чисто и любите в женщине чистоту ее и вдруг убедитесь, что она потерянная женщина, что она развратна - вы полюбите в ней ее разврат, эту гадость, вам омерзительную, будете любить в ней... вот какая бывает любовь!... (Вацуро и др., 1990, с. 205).

Трагическое осмысление любви неоднократно проявлено в мировой художественной литературе, имеет свои специфические особенности и логику эстетического воплощения. По контрасту с художественным наследием Федора Михайловича Достоевского особый интерес в этом плане представляет знаменитый роман Этель Лилиан Войнич Овод, в котором представлен не менее трагический ракурс непростых отношений главного героя Артура и двух важных в его жизни людей. Здесь также фигурирует одержимость человеком, но не столько эротическая, сколько, скорее, платоническая (Джемма), и одержимость 
духовно-родственная (Монтанелли), при этом изрядно сдобренная моральной деструкцией. С одной стороны, явлена драматическая ситуация неразделенной взаимной любви Артура и Джеммы. Разлука, усиливающая обоюдное чувство любви и определяющая ее истинность, здесь уместно напомнить мудрые слова Отто Вейнингера: «любовь проявляется с особой силой в отсутствие любимого существа; ей нужна разлука, известная дистанция для того, чтобы сохранить свою жизненность и силу» (Вейнингер, 1992, с. 228-229); мнимое самоубийство Артура, усложняющее существование Джеммы, поскольку смерть обостряет до предела внутренне состояние тоски, - все это еще более связывает метафизически двух людей. Ни замужество Джеммы, ни легкомысленная связь Артура с танцовщицей Зитой не могут устранить любовь между ними, она непреходяща:

Истинная любовь, рожденная в сокровенных глубинах человека, по-видимому, не может умереть. Она навсегда остается в чувствительной душе... Ее эмоциональный состав не изменится... Судьба может развести его с любимой... Что с того - любовь остается в нем. Таков высший, наивернейший признак подлинной любви: как бы находиться рядом с любимым, быть в общении более тесном, близости более сокровенной, чем пространственные. Это значит пребывать в истинно жизненном контакте. Есть и более точное слово... быть онтологически вместе с любимым, верным его судьбе (Ортега-и-Гассет, 2003, с. 49).

Примечательно, что Зита в данной ситуации выступает в качестве жертвы (но жертвенность эта несколько сомнительна, так как Зита не менее эгоцентрична, чем Артур, оба преследует только свои цели и учитывают свои интересы), поскольку Артур нуждается в ней только как в живом существе, скрадывающем его бесконечное одиночество и метафизическую боязнь темноты:

Я боюсь... темноты. Иногда я просто не могу оставаться один ночью. Мне нужно, чтобы рядом со мной было живое существо... что-то осязаемое. Темнота, кромешная темнота вокруг.. Нет, нет! Я боюсь не ада! Ад - это детская игрушка. Меня страшит темнота внутренняя... там нет ни плача, ни скрежета зубовного, а только тишина... мертвая тишина (Войнич, 1978, с. 143).

Чрезмерные претензии навязчивой и болезненно влюбленной Зиты на взаимность со стороны Артура обречены на провал, ответной реакции любви последовать не может: Артур честен перед ней, будучи верен юношеской любви, затянувшейся более чем на тринадцать лет, причем любви платонической, асексуальной, поскольку еще не было возможности реализовать все уровни этой любви. Драматизм ситуации заключен в том, что обостренное переживание болезненных чувств может быть оправдано только наличием взаимной любви, но не осуществленной, не реализованной по разным причинам, именно тогда страдания одного компенсированы страданиями другого, они имеют высший нравственный смысл и недосягаемую духовную высоту, когда метафизическая связь между любящими настолько сильна, что ни время, ни пространство, ни люди, населяющие это пространство, не способны разорвать возникшее круговращение двух планет по заданной траектории, где посторонним объектам места нет (уровень взаимоотношений Артура и Джеммы). В данной же художественной реальности функционирует иная ситуация, где страдания 
Зиты носят односторонний характер, элемент компенсаторности отсутствует, а боль направлена на внутреннюю разрушительность.

Но проницательность Зиты очень точно угадывает скрытую в Артуре более сильную любовь, поражающую своим драматизмом, выстраданную, прикрытую проявлением ложной ненависти, обусловленной обидой за сокрытие правды о родстве, о кровных узах, определяющей длительное и мучительное непрощение объекта своего преклонения - собственного отца, католического священника монсеньера Монтанелли:

- Зита! Пойми, я не люблю тебя! А если б и любил, то все равно не уехал бы отсюда. В Италии все мои товарищи, с Италией я связан работой.

- И человек, которого ты любишь больше меня! - крикнула она. - Я готова убить тебя!.. При чем тут товарищи! Я знаю, кто тебя держит здесь!

- Перестань, - спокойно сказал он. - Ты сама себя не помнишь, и тебе мерещится бог знает что.

- Ты думаешь, я о синьоре Болле? Нет, меня не так легко одурачить! С ней ты говоришь только о политике. Она значит для тебя не больше, чем я... Это кардинал!

Овод пошатнулся, будто его ударили.

- Кардинал? - машинально повторил он.

- Да! Кардинал Монтанелли, который выступал здесь с проповедями осенью. Думаешь, я не заметила, каким взглядом ты провожал его коляску? И лицо у тебя было белое, как вот этот платок. Да ты и сейчас дрожишь, услышав только его имя!

Овод встал.

- Ты просто не отдаешь себе отчета в своих словах, - медленно и тихо проговорил он. -

Я... я ненавижу кардинала. Это мой заклятый враг.

- Враг он или не враг, не знаю, но ты любишь его больше всех на свете. Погляди мне в глаза и, если можешь, скажи, что это неправда!

... Овод повернулся к ней.

- Да, это правда, - сказал он.

(Войнич, 1978, с. 164)

Поистине, прав Хосе Ортега-и-Гассет, утверждавший о том, что «любящего можно познать по его любви, а вовсе не по предмету любви» (Ортега-и-Гассет, 2003, с. 117). Длительная разлука с дорогим его сердцу человеком, острое желание быть рядом с ним, поведать ему все свои тайны и горести обострили болезненность чувств, те внутренние мучения, которые он длительно скрывал, лишний раз подтверждая проницательные констатации Василия Розанова: «Мы рождаемся для любви. И насколько мы не исполнили любви, мы томимся на свете ...» (Розанов, 2000, с. 91). Юношеский максимализм, затянувшийся на длительное время, индивидуализм и эгоцентризм, пережитые страдания, определяющие неоднозначность поведенческой линии Артура, не приводят к смягчению жестокости по отношению к Монтанелли, мучительно страдающему и переживающему так называемую смерть своего дорогого воспитанника. Очень точно Николай Александрович Бердяев определил подобное состояние (Бердяев, 1990, с. 324):

Есть откровение любви в смерти. Только в смерти есть предельное обострение любви. Любовь делается особенно жгучей и обращенной к вечности. Духовное общение не толь- 
ко продолжается, но оно делается особенно сильным и напряженным, оно даже сильнее, чем при жизни.

Трудно отыскать в мировой художественной литературе произведение, эстетически отражающее более глубокую и более трагическую любовь, нежели представленную в романе Этель Лилиан Войнич, связывающую двух родных людей, не желающих жертвовать своими идейными убеждениями ради взаимного экзистенциального обретения друг друга. Но трагическая ситуация ухода и сына, и отца, как это ни парадоксально, приводит к метафизическому, уже вечному, обретению друг друга.

Повесть Исповедь мужа стоит особняком в русской литературе второй половины 19 века, полутона, полунамеки, тайны и загадки оставил в ней Константин Николаевич Леонтьев. Сюжетная сторона произведения несложна, но несколько необычна. Герой - муж, некто К., в дневниковых записях излагает свою историю: возникшее чувство любви к молодой девушке Лизе, женитьба, трансформация чувства, возникшая двойственность: осознание себя и мужем, и отцом одновременно, причем, вторая ипостась доминирует, что приводит к отказу от супружеских отношений при сохранении платонических чувств; появление нового героя, молодого и красивого грека Маврогени, возникшая страсть между Лизой и молодым красавцем, поощряемая героем-мужем. Финал трагичен: Лиза и Маврогени погибают при кораблекрушении, муж заканчивает жизнь самоубийством (во втором варианте финала повести).

Это произведение привлекало к себе пристальное внимание многих западных исследователей, и все без исключения отмечали в нем реализацию теории эстетического имморализма Константина Николаевича Леонтьева (Мондри, 1992, с. 168). Безусловно, эта реализация затрагивает целый пласт нравственных проблем, причем моральное и имморальное находится здесь в сложноуровневом взаимодействии и переплетении. Сорокапятилетний герой рассуждает в духе философа-экзистенциалиста и имморалиста-ницшеанца:

... Чего я хочу? Я покоен... Здесь хорошо... Общества здесь нет - и слава Богу! Я не люблю общества, на что оно мне? Успехи? Они у меня были: но жизнь так создана, что в ту минуту, когда жаждешь успеха, он не приходит, а пришел, - его почти не чувствуешь ... И в самом деле, что за заслуга любить хорошего человека? То ли дело, вопреки всем, любить порочного, но обворожительного? (Леонтьев, 1991, с. 247-248).

Обворожительный Маврогени в эстетическом отношении вызывает у героямужа объективное восхищение, абсолютно лишенное двусмысленности: «Какое простодушие, какая искренняя, пламенная молодость во всем, в улыбке, в блеске синих очей, в черных коротких кудрях, которые падают на лоб, в жажде жить и веселиться!» (Леонтьев, 1991, с. 278). Мир воспринимается героем сквозь призму аристократической морали жизни в красоте, где существует иная шкала ценностей:

Если уж сметь придавать высшему существу наши свойства, так я бы скорей всего решился придать ему неизмеримое, полное чувство прекрасного. А прекрасное бывает трех главных родов: красота живописная, пластическая, красота драматическая, или действия, и красота чувств... (Леонтьев, 1991, с. 257). 
Выстраивание системы отношений по законам красоты требует от героя жертвоприношения, от собственного эгоцентризма приходится отказаться «Единственная сила, которая в состоянии обуздать врожденный эгоизм, не упраздняя индивидуальности, а, наоборот, утверждая и поднимая ее, это - любовь. Поэтому смысл человеческой любви - оправдание и спасение индивидуальности через жертву эгоизма. Это происходит потому, что посредством любви мы утверждаем безусловное значение другой индивидуальности» (Шестаков, 1999, с. 94). Напомним, что герой повести, женившись на молодой и любимой им девушке (но не любящей, а только благодарной за покровительство в браке), через определенный промежуток времени начинает испытывать двойственность чувств по отношению к ней; муж и отец соединились в нем одном, однако чувства отца вытесняют чувства мужа, брак становится девственным. Но физиологических законов никто не отменял, о чем прекрасно осведомлен герой-муж, чутко осознающий сексуальную привлекательность и потребность жены-дочери. И когда возникает красавец Маврогени, полный нерастраченных сил, потянувшийся к такой же молодой и жаждущей полноты жизни Лизе, герой испытывает чувство удовлетворения, радости за них. Вот где вопрос вопросов!

Неудивительно, что Константин Леонтьев, осуществивший перевод повести на французский язык и отославший ее Просперу Мериме в надежде заручиться поддержкой со стороны прославленного мастера, не получил у него адекватного понимания. Проспер Мериме оказался настолько обескуражен парадоксальной темой произведения, что откровенно скажет в ответном письме Константину Леонтьеву: «Выведенный Вами муж, как мне кажется, не имеет иного побуждения, кроме влечения к состоянию рогоносца, и я его не понимаю» (Леонтьев, 1993, с. 48). Леонтьев, в свою очередь, несколько огорченный и удивленный эстетическим непониманием Мериме, попытается объяснить непонятливому французу стремление отразить в повести мотив «высокого обожествления плотской любви» в границах внеморального эстетизма, вопреки устоявшемся канонам реалистического искусства (Леонтьев никогда не скрывал своего скептического отношения к реализму, подчеркивая столь важный для него факт о том, что эта повесть «возвышается в своих принципах над этой пережеванной вещью... определяемой, как мораль ХІХ века») (Леонтьев, 1993, с. 48).

Стереотипные представления традиционной морали диктуют обратное: любящий муж должен ненавидеть соперника, отстаивать попранные супружеские права и т.п. А муж-отец чуть ли не сам толкает в объятия соперника свою молодую жену. В данной ситуации Леонтьевым включен мотив сводничества, точнее мнимого сводничества. Отто Вейнингер в своей фундаментальной работе Пол и характер отмечал тот факт, что тяга к сводничеству заложена в генах женщины, практически каждая женщина стремится к этому, представителям же сильного пола это не свойственно, за исключением тех, «которые относятся к женственным мужчинам» (Вейнингер, 1992, с. 283) (гомосексуальность здесь неуместна). Герой-муж классифицируется как тип женственного мужчины (определенная мягкость характера, стилевая концепция героя, его эстетические установки). Сводничество само по себе аморально, в чистом виде. Но в данной ситуации мотивация мнимого сводничества мужа-отца снимает с этого явления 
статус безнравственности, по той простой формуле «любить - значит радоваться твоим радостям, а печалиться твоим печалям», где доминирует альтруизм, а не эгоистическое чувство собственности, смешанное нередко с ненавистью (уже по той простой формуле «I hade you with my love!» - с любовью ненавижу, ярким отражением этой формулы являются Позднышев в Крейцеровой сонате Льва Николаевича Толстого, Версилов в Подростке Федора Михайловича Достоевского).

Что здесь - имморализм или наивысшая нравственность? Гедонистические установки мужа-отца, стремление реализации наслаждения неискушенной девушкой никому не причиняют вреда. «Само по себе наслаждение ни нравственно, ни безнравственно. Когда же влечение к наслаждению побеждает в человеке волю к ценности - тогда человек пал» (Вейнингер, 1992, с. 283). Данную ситуацию герой-муж расценивает в границах внеморальности, демонстрируя очередную сентенцию-парадокс: апелляция идет к Богу, богооправданностью земной страсти и любви снимается «вина» с Лизы:

Кто сказал вам, глупцы, что она гибнет? Кто сказал вам, глупцы, что тот, чья рука покрыла землю коврами цветов; тот, кто научил человека воздвигать узорные дворцы и храмы... - кто из вас решил, что волнения чувств и страстей не плодотворны и не угодны ему так же, как и узоры храмов, и узоры цветов, и волнения моря, и волнения музыки?.. Чем упала, чем унизилась она?.. Прочь сомнения! Прочь рабство общих мнений! Пусть питается дешевой и безвредной пищей тот, кто не в силах вынести божественных напитков! (Леонтьев, 1991, с. 286-287).

Эстетически обыгрывая ситуацию садомазохистских проявлений, автор обнаруживает инфернальность героини, типологически родственную демоническим женщинам Достоевского. Свидетельством тому является небольшой эпизод, где в тексте полунамеком отражен особый вид наслаждения, выраженный в столь «изящной» форме (из письма Лизы к мужу):

Вечером Маврогени пришел домой, выбросил букет из окна, а меня схватил за волосы обеими руками и бил головой о стену. Я читала и слыхала о достоинстве женщин, только как ни старалась об этом вспомнить, не могла притворяться. Скажу даже... мне было что-то хорошо; очень было больно, но я не плакала и молча терпела... целовала не только руки, ноги его целовала после этого. А он, он был как безумный от любви (Леонтьев, 1991, c. 303-304).

Сексуальный и психологический садомазохизм находятся в сложном переплетении, где здесь провести грань между моральным и имморальным? Призвать на помощь Фридриха Ницше или вспомнить знаменитое леонтьевское «некое как бы гармоническое сопряжение вражды с любовью». Вопрос остается риторическим. Юрий Иваск, анализируя эту повесть, усмотрел в центральном персонаже произведения воплощенный образец альтруизма в чистом виде:

В «Исповеди» живет не только супергерой (муж), как во всех других повестях Леонтьева, но живут и те двое - Лиза, Маврогени. Они не «игрушки»» супергероя: у них есть своя жизнь, свои желания, и муж их изнутри понимает, потому что очень любит. Вся эта драма - явление необычное в леонтьевском мире (Иваск, 1995, с. 327). 
Однако альтруизм мужа-отца не так наивен и прост, как может показаться на первый взгляд. Характер героя, как известно, структурирован двумя уровнями: линией отца и линией мужа. Двуплановость же героя не реализуется гармонично, бессознательно или осознанно (это не столь важно), но линия мужа все явственней заявляет о себе. Фактически, герой проводит эксперимент с собственной женой, эксперимент, конечный результат которого, по его подсчетам, должен сработать на него, а не на любовника. Отпуская ее по волнам страстной любви, он надеется, он почти уверен в обреченности этой страсти на скорый финал (его слова: «Страсть не совершила полного своего круга... Не дать ли ей допить чашу до дна?..»), что и происходит, но героиня не успевает встретиться со своим преданным мужем-отцом и выразить свое преклонение перед открывшимися ей достоинствами зрелости, а не ветреной и беспечной юности, ее настигает смерть. Экспериментатор наказан, жизнь его становится бессмысленной и ненужной: «Смерть ее была случайна... Но мне - мне-то что же делать? Я-то разве не погиб дотла?.. Что я? Зачем я? Не она погибла - я, я погиб без нее» (Леонтьев, 1991, с. 307).

Подобную ситуацию невозможности существования без любимого человека, невозможности замены его кем-либо другим очень точно характеризует Эрих Фромм в своей концептуальной работе Искусство любить:

Во многих социальных ролях и функциях конкретного человека можно заменить, заместить, сменить, только не в любви. В этой сфере жизни индивид имеет, таким образом, высшую ценность, высшее значение по сравнению со всем остальным. Здесь человек не функция, а он сам, в своем конкретном и непосредственном абсолюте. Именно поэтому только в любви человек может прочувствовать смысл своего существования для другого и смысл существования другого для себя. Это высший синтез смысла существования человека (Фромм, 2004, с. 117).

Однако, сохраняя бытие-в-себе, запутываясь в сетях эгоизма и альтруизма, пытаясь манипулировать человеческой жизнью, герой не в силах смоделировать бытие-в-нас, жизненная, онтологическая перспектива нарушена и приводит к гибели.

В Крейцеровой сонате все гораздо сложнее. Здесь нет ни полутонов, ни полунамеков, беспощадный реализм Льва Николаевича Толстого обнажает самое сокровенное до предела. Существует восемь редакций повести, она произвела истинный переполох и смятение в умах читателей. Вот что писал Константин Победоносцев о Крейцеровой сонате:

Прочел я первые две тетради: тошно становилось - мерзко до циничности показалось. Потом стал читать еще (сразу все читать душа болит), и мысль стала проясняться. Только в три приема прочел все - и задумался... Да, надо сказать - ведь все, что тут написано - правда, как в зеркале... Произведение могучее. И когда я спрашиваю себя, следует ли запретить его во имя нравственности, я не в силах ответить да (Шкловский, 1974, с. 526).

Герой Толстого двуплановой структурированностью не отличается, однако и он балансирует между моральным и имморальным. Мотив сводничества ярко представлен у Толстого, Позднышев осознанно подталкивает Трухачевского к сближению с собственной женой, всякий раз подавляя в себе чувство 
ревности, ненависти по отношению к потенциальному сопернику. Всякий раз реализуя это мнимое сводничество, Позднышев моделирует ситуацию взрывоопасную, собственным сознанием и поступками приближает финальную трагическую черту. Он так же экспериментирует с собственной женой, безжалостно манипулируя ее внутренним и внешним миром, провоцируя ее на поступки, вызывающие дополнительную ревность.

Героиня Толстого страдает истерическими припадками, в сущности, неся в себе тот же полюс инфернальности, что и героини Достоевского. Она также наделена психологическими садомазохистскими наклонностями, разрушающими ее внутреннее состояние, и муж бессилен ей помочь, он и не стремится к этому, барахтаясь в плену имморализма. Толстой обнажил моральную проблему невозможности существования вдвоем, совместное стремление к взаимному уничтожению. «Вечный трагизм семьи в том, что мужчина и женщина представляют разные миры, и цели их никогда не совпадают» (Бердяев, 2006, с. 263). Муж и жена не становятся необходимым дополнением друг друга ни в моральном, ни в духовном, ни в интеллектуальном, ни в сексуальном планах. «Если любовь-эрос не соединяется с любовью-жалостью, то результаты ее бывают истребительные и мучительные. В эросе самом по себе есть жестокость, он должен смиряться жалостью, caritas» (Бердяев, 1990, с. 81). Происходит бессмысленная борьба двух эгоизмов, бессмысленная борьба против собственного пола, причем, куцее скудоумие в вопросах сексуальной культуры прикрывается претензией на якобы исключительную нравственность отказа от половых отношений.

Лев Николаевич Толстой, как ни странно, повторяет ситуацию «подполья» Федора Михайловича Достоевского, подпольный герой Позднышев, отражая бытие-в-себе, лелея и пестуя собственный эгоцентризм, разрушает бытие-в-нас, как собственно и его жена не нацелена на созидание бытия-в-нас, получается такое «случайное семейство» (как у Достоевского и Леонтьева), ведущее в никуда, а имморальное или моральное бессильно что-либо здесь изменить, царствуя в высотах абстракции и снисходительно взирая на мир безутешной конкретики.

Таким образом, осознание Федором Достоевским, Константином Леонтьевым и Львом Толстым дуализма любви позволяет определить ее внеморальность, вненравственную принадлежность. Безусловно, эти русские писатели нравственное, этическое в онтологическом плане отрицать не могли, но любовь не умещается в систему сугубо моральных ценностей, она выходит за ее пределы, она выше нравственности, и в этом заключается ее антиномичность и парадоксальность. Любовь всегда связана с онтологией человека, но «человек есть тайна», а любящий человек - тайна тайн. Поэтому в притягательном художественном мире русских классиков нет ответов на многие вопросы человеческого бытия, но только одно ясно - непостижимость человека влечет непостижимость любви.

И в заключение, следует напомнить о том, что все дороги, как известно, ведут в Рим, но у любящего свой Рим и свой Крест, на котором начертано одно единственное имя, единственное и неповторимое в своей исключительности и персонифицирующее в себе целый мир, многогранную малую вселенную, столь притягательную для его души и определяющую смысложизненную 
доминанту, его экзистенциальную константу полноты жизни в любви. Главное же и самое трудное заключается в том, чтобы носитель этого единственного имени, оставаясь всегда путеводной звездой на встречном пути (именно на встречном), сумел оправдать столь высокие надежды любящего - самого ранимого и самого благородного в своей потрясающей верности высокому чувству человека.

\section{Библиография}

Анненский, И. (1988). Избранные произведения. Ленинград: Художественная литература. Бердяев, Н. (1990). Самопознание. Москва: Международные отношения.

Бердяев, Н.А. (1994). Философия творчества, культуры и искусства: в 2 m. Москва: Искусство.

Бердяев, Н. (2006). О назначении человека. Москва: АСТ.

Борисов, В., Рогинский, А. (1990). О Достоевском: творчество Достоевского в русской мысли 1881-1931 г2. Москва: Книга.

Вацуро, В. Э. и др. (ред.) (1990). Достоевский Ф. М. в воспоминаниях современников: в 2 m. Т. 2. Москва: Художественная литература.

Вейнингер, О. (1992). Пол и характер. Москва: Издательский центр «Терра».

Войнич, Э. Л. (1978). Овод. Минск: Народная асвета.

Гуревич, П. С. (сост.) (1988). Проблема человека в западной философии. Москва: Прогресс.

Диккенс, Ч. (1985). Тайна Эдвина Друда. Минск: Вышэйшая школа.

Достоевский, Ф. М. (1976). Полное собрание сочинений: в 30 m. Т. 14. Ленинград: Наука.

Зеньковский, В. В. (1991). Проблема красоты в миросозерцании Достоевского. Искусство кино, № 11 .

Иваск, Ю. (1995). Константин Леонтьев (1831-1891). Жизнь и творчество. В: Леонтьев, К. Н. Pro et contra: личность и творчество К. Леонтьева в оценке русских мыслителей и исследователей: антология. Кн. 2. Санкт-Петербург: Русский христианский гуманитарный институт.

Камю, А. (1978). Кириллов. В: Писатели Франции о литературе. Москва: Прогресс.

Леонтьев, К. (1991). Египетский голубъ. Москва: Современник.

Леонтьев, К. (1993). Избранные письма. Санкт-Петербург: Пушкинский фонд.

Леонтьев, К. Н. (1995). Pro et contra: личность и творчество К. Леонтьева в оценке русских мьслителей и исследователей: Антология. Кн. 2. Санкт-Петербург: Русский христианский гуманитарный институт.

Льюис, К. С. (1989). Любовь. Вопросы философии, № 8.

Мондри, Г. (1992). Попытка типологизации творчества К. Леонтьева на примере анализа Исповеди мужа. Вопросы литературы, № 2.

Моэм, С. (1981). Братья Карамазовы Достоевского. В: Писатели Англии о литературе. Москва: Прогресс.

Ницше, Ф. (1992). По ту сторону добра и зла: к генеалогии морали. Минск: Беларусь.

Ортега-и-Гассет, Х. (2003). Этюды о любви. Санкт-Петербург: Издательство Ивана Лимбаха.

Розанов, В. (2000). Опавщие листья. Санкт-Петербург: Амфора.

Фромм, Э. (2004). Искусство любить. Санкт-Петербург: Азбука-классика.

Храмов, Е. (1992). От переводчика. В: Маркиз де Сад. Новая Жюстина. Москва: НИК.

Шестаков, В. П. (1991). Русский эрос, или философия любви в России. Москва: Прогресс. 
Шестаков, В. П. (1999). Эрос и культура: философия любви и европейское искусство Москва: Республика; ТЕРРА-Книжный клуб.

Шніп, В. (уклад), (2016). Ева у пошуках Адама: аповесці, апавяданні. Мінск: Мастацкая літаратура.

Шкловский, В. (1974). Собрание сочинений: в 3 m. Т. 2. Москва: Художественная литература. 